ORIGINAL ARTICLE

\title{
Foliar anatomy of Rhynchosia spp. (Leguminosae, Papilionoideae) from Roraima state, northern Brazilian Amazon
}

\author{
Andréia Silva FLORES ${ }^{1,2^{*}}$, Eduardo de Souza COSTA ${ }^{3}$, Germana Bueno DIAS ${ }^{2,4}$ \\ Instituto de Amparo a Ciência, Tecnologia e Inovação de Roraima - IACTI-RR, Herbário do Museu Integrado de Roraima. Av. Brigadeiro Eduardo Gomes s.n., Parque \\ Anauá, 69305-010 Boa Vista, Roraima, Brazil \\ 2 Universidade Estadual de Roraima - UERR, Programa de Pós-graduação em Agroecologia, Campus Boa Vista, Rua Sete de Setembro 231, 69306-530, Boa Vista, \\ Roraima, Brazil \\ 3 Universidade Federal de Roraima - UFRR, Centro de Estudos da Biodiversidade, Curso de Ciências Biológicas, Campus Paricarana, Av. Ene Garcez 2413, 69304-000 \\ Boa Vista, Roraima, Brazil \\ ${ }^{4}$ Universidade Federal de Roraima - UFRR, Programa de Pós-graduação de Ciências da Saúde, Campus Paricarana, Av. Ene Garcez 2413, 69304-000, Boa Vista, \\ Roraima, Brazil \\ * Corresponding author: andreiasflores@gmail.com
}

\section{ABSTRACT}

Comparative studies on the structure of foliar anatomy in four species of Rhynchosia from Roraima state (northern Brazilian Amazon) were carried out to identify additional morphological characters to support the definition of the systematic boundaries among the species. Fully expanded leaves, including the petioles, were collected from the upper nodes of a plant's stem. Anatomical characters were observed in cross-sections of the middle portion of leaflets and petiole segments. Presence and distribution of glandular trichomes, continuity of sclerenchyma around the vascular bundles in leaflet blades and the conformation of the area between the two ridges of petioles were important characters to distinguish among the species of Rhynchosia. For the first time we report a distinct multicellular gland-like structure which we found in the petioles of three species.

KEYWORDS: Fabaceae, Phaseoleae, morphology, leaf anatomy, Neotropics

\section{Anatomia foliar de Rhynchosia spp. (Leguminosae, Papilionoideae) de Roraima, Amazônia setentrional}

\section{RESUMO}

Estudos comparativos da estrutura anatômica foliar foram realizados para identificar caracteres morfológicos adicionais para a caracterização sistemática de quatro espécies de Rhynchosia ocorrentes em Roraima. Folhas completamente expandidas, incluindo o pecíolo, foram coletadas nos nós superiores da planta. Os caracteres anatômicos foram estudados a partir de observaçôes de cortes tranversais da região mediana de folíolos e pecíolos. A presença e a distribuição de tricomas glandulares, a continuidade do esclerênquima em torno dos feixes vasculares nos folíolos e a conformaçáo da região entre as duas alas nos pecíolos se mostraram importantes caracteres para a distinção das espécies amazônicas de Rhynchosia. Também foi registrada pela primeira vez a ocorrência de uma diferenciada estrutura similar a glândula nos pecíolos de três espécies.

PALAVRAS-CHAVE: Fabaceae, Phaseoleae, morfologia, anatomia foliar, Neotrópicos

\section{INTRODUCTION}

The genus Rhynchosia Lour. (Leguminosae, Papilionoideae) belongs to the tribe Phaseoleae, subtribe Cajaninae and comprises some 230 species, of which 55 are endemic to the Neotropics, which are considered a center of diversity for Rhynchosia (Grear 1978; Lewis et al. 2005). Brazil harbours 18 species, of which five were reported for the northern region of Brazil (BFG 2015). Four of these Amazonian species have been registered for the state of Roraima, where they occur mostly in savanna vegetation (Grear 1978; Lewis et al. 2005; Hirt and Flores 2012). Species of Rhynchosia are climbing or twining herbs with trifoliolate leaves and glandular trichomes covering the entire plant (Miotto 1988; Hirt and Flores 2012).

Foliar anatomical characters, mainly regarding the presence and type of secretory structures, may be useful characters for the delimitation of Phaseolae taxa (Melo et al. 2010; Brubaker and Lersten 1995; Lackey 1978; Tourn 
et al. 2009; Vargas et al. 2015). Anatomical data on the Rhynchosia leaflets and petiole are available for 21 species (Solereder 1908; Metcalfe and Chalk 1950; Bhattacharyya and Marheshwari 1970; Lackey 1978; Melo et al. 2010; Vargas et al. 2015). Anatomical studies of Rhynchosia revealed a variation of glandular trichomes present on the leaflet blade in some species. The presence, absence, and position of these glandular structures, denominated as extrafloral nectaries, were considered useful for the distinction among groups of Indian species (Bhattacharyya and Marheshwari 1970). Besides the presence and distribution of glandular trichomes, other foliar anatomical characteristics, such as the shape of the epidermal cells and vascular bundles, and sclerenchyma discontinuity in leaflet blades, were important to distinguish some Brazilian species (Vargas et al. 2015). No detailed micro-morphological studies on petiole anatomy in Rhynchosia have been published. Studies on five African species revealed the utility of glandular trichomes for the distinction of these species (Jaca and Moteetee 2018; Jaca et al. 2018).

The four species registered for the state of Roraima are $R$. melanocarpa Grear, R. minima (L.) DC., R. phaseoloides (Sw.) DC., and R. schomburgkii Benth. They are mainly distinguished by flower and legume morphology. The lack of useful vegetative features makes it difficult to identify them in the vegetative period (Hirt and Flores 2012). Rhynchosia schomburgkii has the most restricted distribution among these four species, occurring only in northern South America, in Venezuela, Guyana, Brazil (Roraima) and western Colombia. The other three species have a broader distribution throughout South America (Grear 1978).

The aim of the present study was to describe the foliar anatomy in the four species of Rhynchosia occurring in the state of Roraima, in order to introduce additional morphological characters to support species delimitation.

\section{MATERIAL AND METHODS}

Leaflets and petioles were collected from natural populations in open areas and forest borders in savanna vegetation in two municipalities in the state of Roraima. Vouchers were deposited in the Herbarium of the Museu Integrado de Roraima (MIRR), Roraima State, Brazil [R. melanocarpa: Roraima, RORAIMA: Boa Vista, Campus UFRR Cauamé, 14/V/2009, A.P.M. Hirt et al. 04 (MIRR); R. minima: Roraima, Boa Vista, Bosque dos Papagaios, 24/II/2009, A.S. Flores et al. 2221 (MIRR); R. phaseoloides: Roraima, Amajari, Serra do Tepequém, área da RPPN do SESC Tepequém, 15/X/2008, R. Schütz-Rodrigues \& R. Serafim 2128 (MIRR) and R. schomburgkii: Roraima, Bonfim, 18/XI/2009, A.P.M. Hirt et al. 07 (MIRR)].

A brief characterization of the external leaf morphology was made using an SZ 51 Olympus stereomicroscope. For the anatomical data, fully expanded leaflets and their petioles were collected from the upper nodes and immediately fixed in the field in formalin acetic alcohol (FAA 70) for 24 hours and then transferred to $70 \%$ ethanol (Johansen 1940). Anatomical characters were observed in cross-sections of the middle portion of leaflet and petiole segments measuring $5 \mathrm{~mm}$, sectioned manually with a steel blade, stained with Astra blue and safranin and mounted in glycerin jelly (Kraus and Arduin 1997).

Morphological types of glandular trichomes were identified following Vargas et al. (2015), who recognized four types of glandular trichomes (ellipsoid capitated trichomes, spheric glandular trichomes, vesicular glands, and bulbous-based trichomes). Photomicrographs of the material were obtained with an optical Nikon Eclipse E200 microscope coupled with a Motican 10 camera, and the images were captured using the Motic Image Plus 2.0 software and measured using Image Pro Plus 2.0 software. Images were processed with Image-J and Photoshop 6.0 softwares, and the boards mounted using CorelDRAW 12.

\section{RESULTS}

All four species had pinate-trifoliolate and petiolate leaves (Figure 1A). The petiole of each leaf had two stipules, either linear or subulate, and caducous or persistent. Leaflets and petioles were densely haired, with golden sessile glands scattered on the surface.

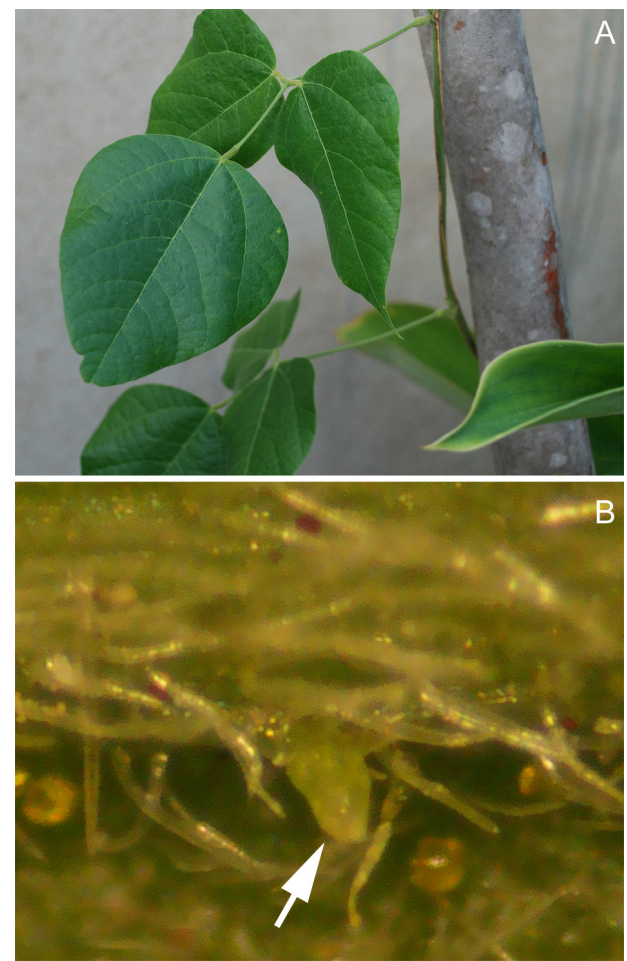

Figure 1. Leaf of Rhynchosia phaseoloides. A. Vegetative branch with trifoliolate leaves. B. Petiole surface seen in a stereomicroscope, showing multicellular glandlike structures (white arrow), and glandular and non-glandular trichomes. Scale bars $=100 \mu \mathrm{m}$. This figure is in color in the electronic version. 


\section{Leaflet blade anatomy}

In transverse section, the leaflet epidermis was organized in a single layer of cells bearing a thin cuticle. All species had hypostomatic leaflets with stomata above the ordinary epidermal cells. The outline of epidermal cells in the midrib region of the leaflet was papillose on the abaxial surface and irregular in the adaxial surface in all taxa.

All species displayed secretory and non-glandular trichomes (Figure 2). The non-glandular trichomes consisted of one single short basal cell and two extremely elongated apical cells present in both surfaces of the leaflet blade (Figure 2A). The glandular trichomes were differentiated in four morphological types, as found in Vargas et al. (2015): type 1 - spherical trichomes with semicircular apical cells (Figure 2B); type 2 - ellipsoid trichomes (Figure 2E); type 3 - bulky capitate trichomes consisting of a narrow stalk supporting a large apical head (Figure 2D), and type 4 - bulbous-based trichomes consisting of a single epidermal cell supporting a bulbous cell complex, from the top of which one or two ranks of long cells extend (Figure 2C).

There were differences among the species in distribution and presence of glandular trichomes. On the abaxial surface, $R$. melanocarpa, R.minima, and $R$. schomburgkii had trichomes of type 1 . Type 2 and 4 trichomes were present in all four species, while type 3 trichomes were featured in all species, except $R$. melanocarpa. On the adaxial surface, type 1 trichomes were present in $R$. minima and $R$. phaseoloides, type 2 in $R$. melanocarpa, type 3 in $R$. minima, and type 4 in $R$. melanocarpa, $R$. schomburgkii, and $R$. minima.

All species had collateral mesophyll with two layers of palisade parenchyma in three species, while $R$. minima had one layer or one to two layers of palisade parenchyma. In $R$. schomburgkii, the spongy parenchyma had cells with intermediate forms among the palisade and spongy parenchymas, and the cells of the palisade parenchyma invaded the central vein area. In $R$. melanocarpa and $R$. schomburgkii the mesophyll was compacted, with few intercellular spaces. In all species, we observed paraveinal mesophyll above the spongy parenchyma and adjacent to the palisade layer, usually with a red-brown secretion (Figure 3B). Crystalliferous and phenolic idioblasts were dispersed in the palisade parenchyma of all species.

Leaflets in Rhynchosia had a biconvex central vein. The bundles were of medium caliber and the central vein bore a sclerenchymal endoderm sheath. Sclerenchymal bundle sheath extensions were observed in $R$. melanocarpa and $R$.
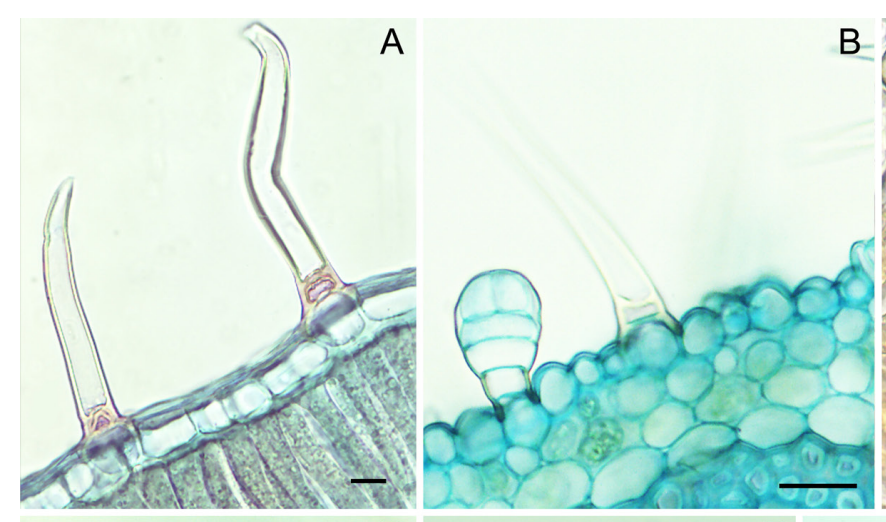

B
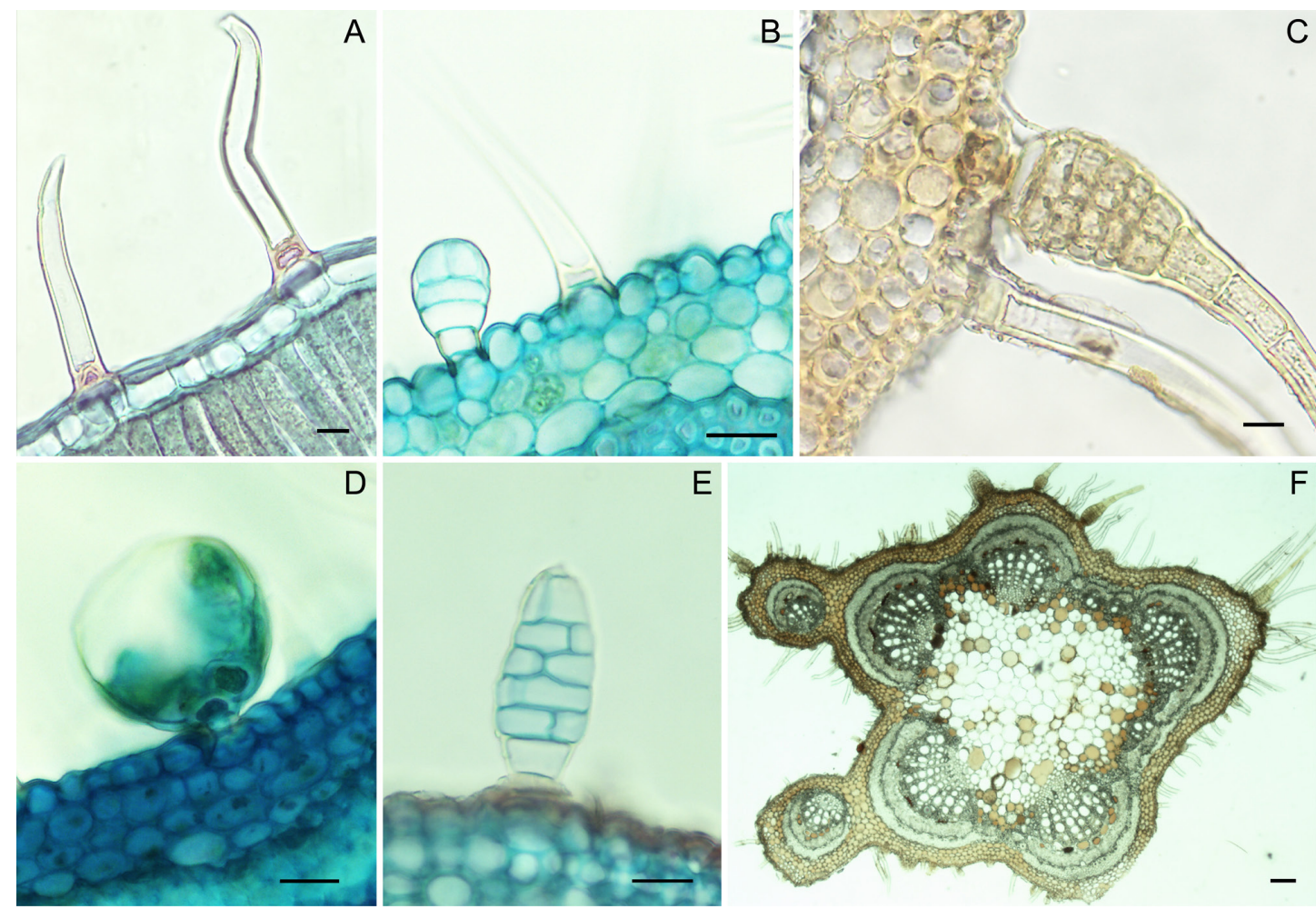

$\mathrm{E}$

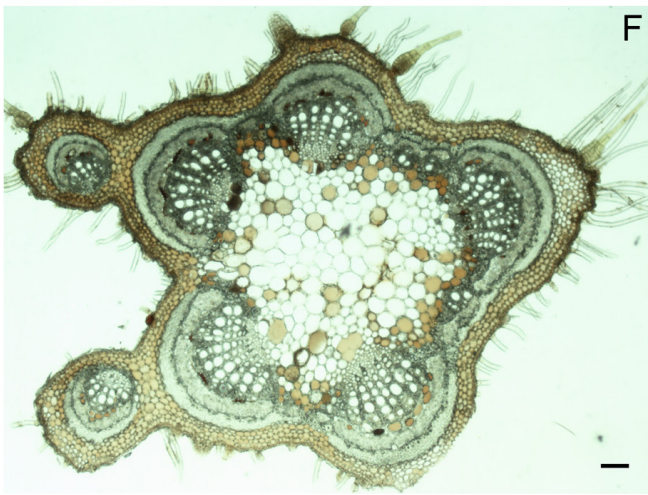

Figure 2. Foliar trichomes in four Rhynchosia species known from Roraima state (northern Brazil). A. Tector trichome on the leaflet blade of R. schomburgkii; B. Glandular trichome of type 1 (spherical) in the petiole of R. minima; C. Glandular trichome of type 4 (bulbous based) in the petiole of R. schomburgkii; D. Glandular trichome of type 3 (bulky) in the petiole of R. phaseoloides; E. Glandular trichome of type 2 (ellipsoid) in the petiole of R. melanocarpa; F. Cross section of the middle region of the petiole of $R$. schomburgkii showing glandular and non-glandular trichomes. Scale bars $=100 \mu \mathrm{m}$. This figure is in color in the electronic version. 
schomburgkii. In R. melanocarpa and $R$. phaseoloides the central vascular bundles were continuously covered by sclerenchyma, whereas the sclerenchyma was discontinuous in R. minima and R. schomburgkii. Prismatic crystals were present in endoderm cells in sclerification (Figure 3A).

Cells containing starch grains were detected in the parenchyma near the central vascular bundle, and less frequently in the mesophyll. Phenolic idioblasts were observed in the paraveinal mesophyll, the spongy parenchyma, and, to a lesser extent, in the phloem tissue of all species.

\section{Petiole anatomy}

Transverse sections of petioles showed two basal wings in all species studied (Figure 4). The epidermis of the petiole was uniseriate and covered by a thick cuticle and non-glandular and secretory trichomes in its extension. The epidermis cells are rounded with stomata in protuberances or just above the level of the epidermis (Figure 3C). The non-glandular and glandular trichomes were of the same morphological types as in the leaflets. All species presented all four types of glandular trichomes and non-glandular trichomes (Figure 2F).

We observed a gland-like multicellular structure resulting from a projection of the cortex and probably with a secretory function (Figure 3D). This structure was an elongated projection standing from the cortex and presented a stoma at its apex. A brown content was observed in the structure, possibly relating to the presence of phenolic compounds. Its outline epidermis cells had a thick cuticle while its interior was constituted by cells of the same format as those occurring in the cortex. This structure could be seen in a stereomicroscope and was sparsely distributed on the canaliculate petiole surface (Figure 1B).

In the cortical region, there was a discontinuous collenchyma sheath above a fundamental parenchyma with compact cells and an extensive sheath of fibers surrounding
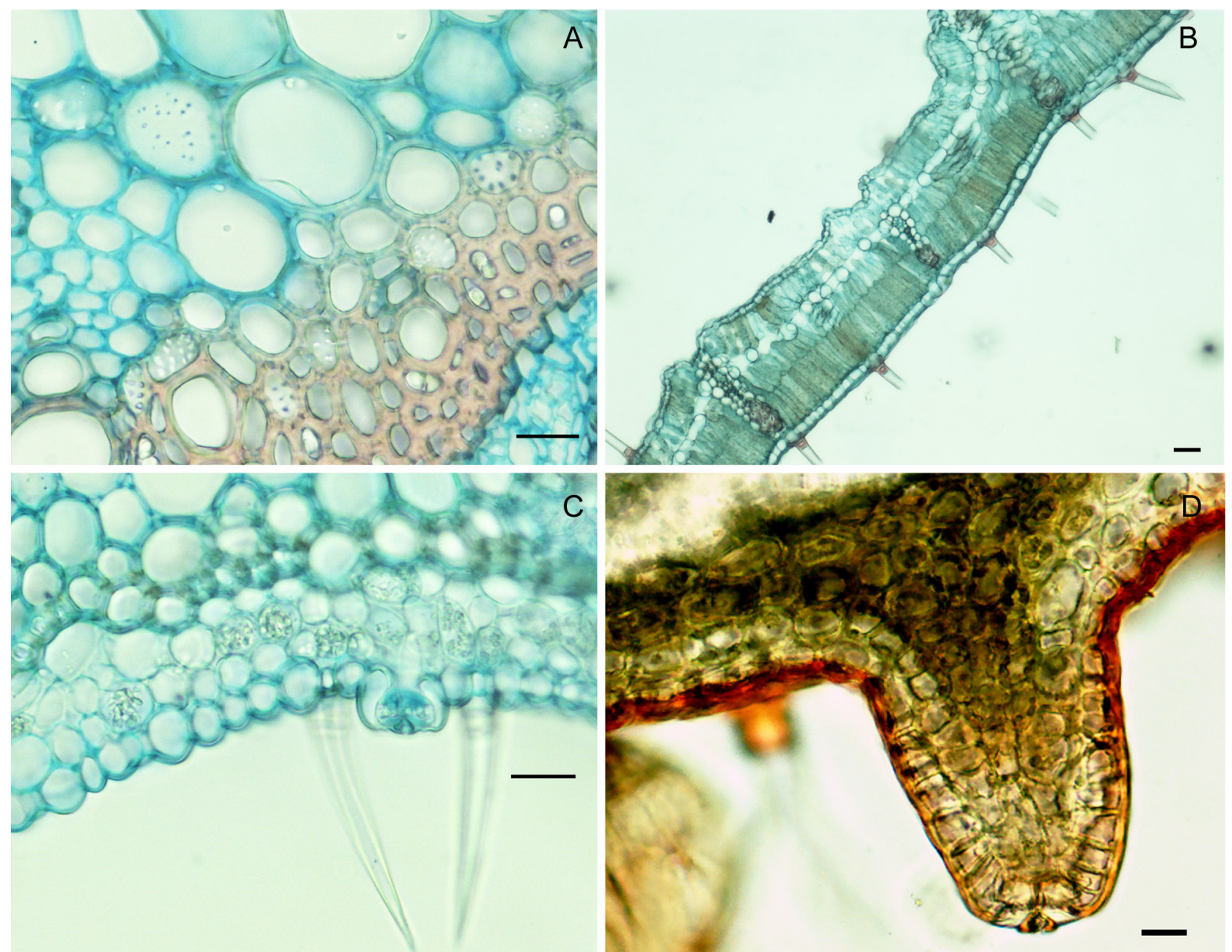

Figure 3. Anatomical details of leaves of four Rhynchosia species known from Roraima state (northern Brazil). A. Prismatic crystals in endoderm cells in the midrib region of the leaflet blade in $R$. phaseoloides; B. Paraveinal mesophyll in R. schomburgkii; C. Stomata in the petiole of R. minima; D. Details of multicellular gland-like structures in the petiole of $R$. melanocarpa. Scale bars $=100 \mu \mathrm{m}$. This figure is in color in the electronic version. 
the vascular system. The vascular system had five collateral vascular bundles and two accessory vascular bundles located in ridges of the adaxial side of the petiole. These accessory bundles presented a dense range of fibrous layers at the phloem pole, except in $R$. minima which had few layers of fibers. The conformation of the area between the two ridges was straight in $R$. phaseoloides, curved in $R$. melanocarpa and $R$. minima, and cordiform in R. schomburgkii (Figures 4 A-B).

Sclerified cells occurred sparsely in the region near the vascular system, while the fenolic idioblasts and starch-containing cells were frequent in the entire petiole of all four species.

Our results confirmed the diagnostic value of specific foliar anatomical features in Rhynchosia (Table 1) and allowed for the development of the following identification key for the Rhynchosia species occurring in Roraima state.
Key of identification of Rhynchosia species from Roraima state (northern Brazil) based on foliar anatomical characters:

1. Area of the two ridges of petiole straight ........ R. phaseoloides

1'. Area of the two ridges of petiole curved or cordiform ........ 2

2. Adaxial surface of leaflets with bulky capitate trichomes; sclerenchymal bundle sheath extensions in leaflets and glandlike multicellular structure in petioles absent R. minima

2'. Adaxial surface of leaflets without bulky capitate trichomes; sclerenchymal bundle sheath extensions in leaflets and glandlike multicellular structure in petioles present .3

3. Continuous sclerenchyma midrib; area of the two ridges of petiole curved ................................ R. melanocarpa

3'. Discontinuous sclerenchyma midrib; area of the two ridges of petiole cordiform R. schomburgkii
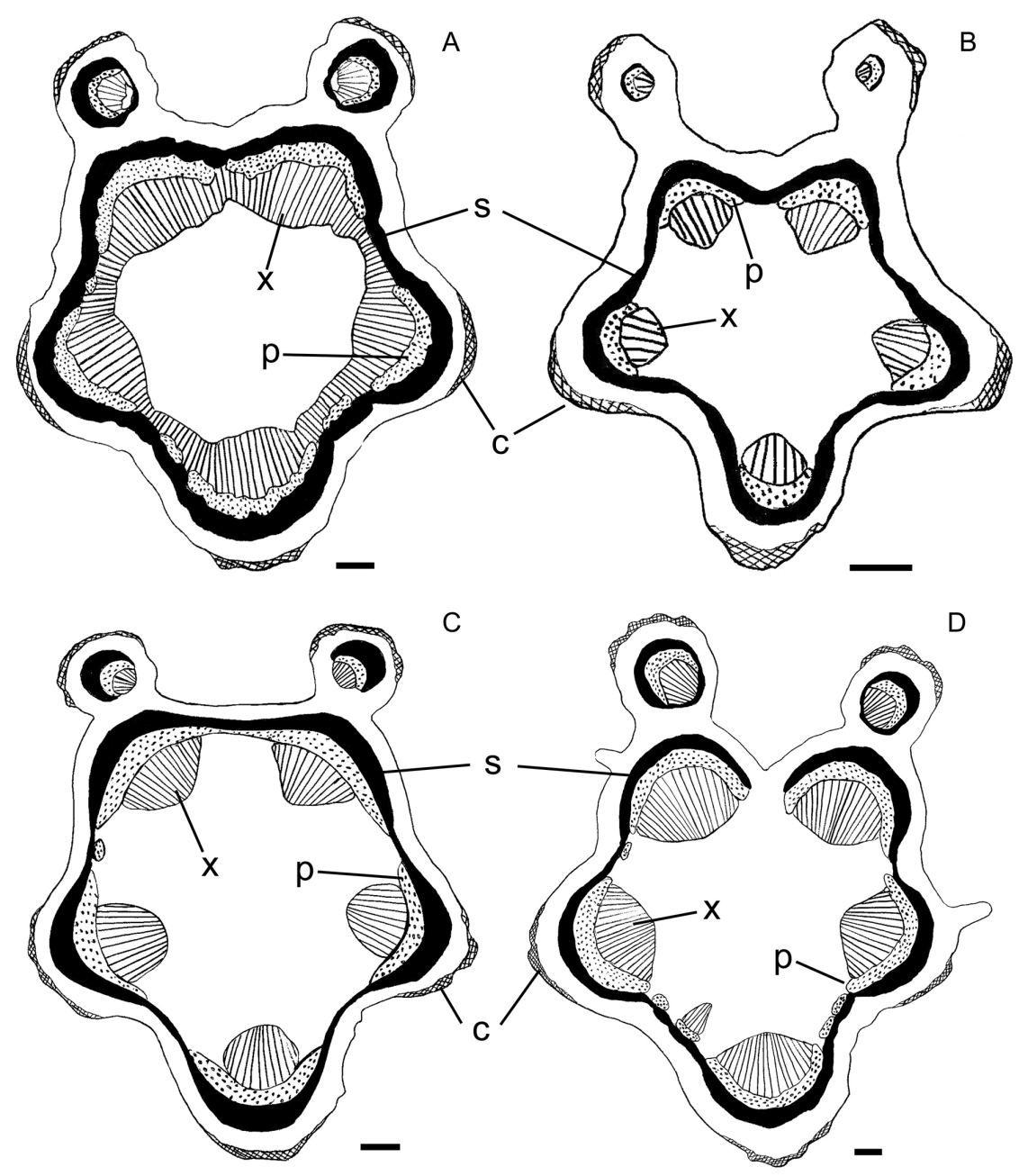

Figure 4. Diagrams of the petiole cross-section of Rhynchosia species from Roraima state (northern Brazil). A. R. melanocarpa; B. R. minima; C. R. phaseoloides; D. R. schomburgkii. S: Sclerenchyma; C: Collenchyma; X: Xylem; P: Phloem. Scale bars $=100 \mu \mathrm{m}$. 
Table 1. Anatomical characters of leaflets and petiole with taxonomic relevance in four species of Rhynchosia from Roraima state (northern Brazil). Glandular trichomes in the abaxial surface (AB) and adaxial surface (AD): 1. spherical trichomes; 2. ellipsoid trichomes; 3. bulky capitate trichomes; 4. bulbous-based trichomes. Sclerenchymal bundle sheath extensions present (+) or absent (-). Continuous sclerenchyma midrib (C); Discontinuous sclerenchyma midrib (D). Gland-like multicellular structure present $(+)$ or absent $(-)$ in petioles. Conformation of the area between the two ridges of petiole.

\begin{tabular}{|c|c|c|c|c|c|c|}
\hline \multirow{2}{*}{ Species } & \multicolumn{2}{|c|}{ Glandular trichomes } & \multirow{2}{*}{$\begin{array}{l}\text { Bundle sheath } \\
\text { extensions }\end{array}$} & \multirow{2}{*}{$\begin{array}{l}\text { Sclerenchyma } \\
\text { midrib }\end{array}$} & \multirow{2}{*}{$\begin{array}{l}\text { Gland-like } \\
\text { (petioles) }\end{array}$} & \multirow{2}{*}{ Ridge of petiole } \\
\hline & $A B$ & $A D$ & & & & \\
\hline Rhynchosia melanocarpa & $1,2,4$ & 2,4 & + & C & + & curved \\
\hline Rhynchosia minima & $1,2,3,4$ & $1,3,4$ & - & D & - & curved \\
\hline Rhynchosia schomburgkii & $1,2,3,4$ & 4 & + & D & + & cordiform \\
\hline Rhynchosia phaseoloides & $2,3,4$ & 1 & - & C & + & straight \\
\hline
\end{tabular}

\section{DISCUSSION}

The foliar anatomical features described in this study were in accordance with the general patterns observed in previous studies (Metcalfe and Chalk 1950; Lackey 1978; Vargas et al. 2015). We identified anatomical features of leaflets and petioles that are useful for the distinction among species. The presence and position of glandular trichome types, sclerenchymal bundle sheath extensions, discontinuity of sclerenchyma in vascular bundles on leaflets, the shape of the area between wings with accessory vascular bundles on the petiole, and the presence of a gland-like multicellular structure were important markers in the characterization of the four species of Rhynchosia that occur in Roraima.

The four Rhynchosia species shared features found in other taxa of Cajaninae (Lackey 1978; Solereder 1908), sharing the same glandular types of trichomes on the leaflet blade and petioles, specifically regarding the presence of bulbous-based trichomes and vesicular glands. Lackey (1978) classified the glandular trichomes found in Rhynchosia into three morphological types: unstalked glands, vesicular glands, and bulbous-based hairs. Vargas et al. (2015) carried out a study on glandular types in seven taxa of the genus in order to evaluate the potential diagnostic value of these anatomical traits for taxonomic assignment. In the classification of glandular types as "capitate" types proposed by Vargas et al. (2015), including the four types already referred to (spherical, ellipsoid, bulbousbased and bulky capitate), the bulky capitate type corresponds to the vesicular glands described by Lackey (1978) in addition to non-glandular trichomes with one to three cells. The new organization by Vargas et al. (2015) added the ellipsoid hair to the three types by Lackey (1978), who did not differentiate unstalked hairs. In our material it was possible to distinguish ellipsoid from spherical hairs, which was important for the distinction among species. The distribution of glandular trichomes on leaflets of $R$. minima and $R$. melanocarpa disagreed with Vargas et al. (2015), i.e. we were not able to find the trichomes of type 2 on the adaxial side of leaflets in $R$. minima, neither those of type 1 on the adaxial and those of type 3 on the abaxial surface of leaflets in $R$. melanocarpa.
The bulky capitate trichomes (corresponding to the vesicular glands of Lackey 1978) were considered as extrafloral nectaries by Bhattacharyya and Marheshwari (1970) and Melo et al. (2010a, b). Extrafloral nectaries and their interactions with ants are known from many taxa in Leguminosae, and morphology, location, and distribution of these structures on plants are diverse (Díaz-Castelazo et al. 2005; Melo et al. 2010a, b; Marazzi et al. 2013). However, Bhattacharyya and Marheshwari (1970) and Melo et al. (2010a, b) did not analyze the sweetness or sugar composition of these nectaries. In many other families, peltate trichomes with similar morphological structure to those observed in our species of Rhynchosia are not nectaries but glandular yellow oil secretor trichomes (Lersten and Brubaker 1987).

A distinct secretory structure was described in leaflets of Eriosema grearii Cândido \& Fort.-Perez, referred to as a secretory-based trichome with multicellular, unbranched and uniseriate structure, comprised of an elongated, acuminate apical cell, two intermediate cells, and a large, hexagonal basal cell bearing a large vacuole filled with flocculent secretory material (Candido et al. 2016). Our study showed a very distinct structure that seems to be glandular by the presence of redbrown material at the stomata on its apex. We consider them as probable gland-like multicellular structures until confirmation through histochemical tests and ontogeny studies.

The differences in leaf anatomy among the four species appeared to be consistent. The continuity of sclerenchyma around the vascular bundles of the leaflet midrib was crucial for species distinction, as noted in Vargas et al. (2015),. However, the shape of the epidermal cells and the shape of the vascular bundle in the leaflets did not prove to be useful characters in the Roraima species. The absence of glandular trichomes on the adaxial surface of leaflets and the orbicular area between the two ridges on the petiole may be useful anatomical characters to distinguish $R$. schomburgkii from the other species. Previous studies have shown that this species also has distinctive floral and seedling morphology (Grear 1978; Rodrigues et al. 2012). Rhynchosia minima could be distinguished by the absence of a gland-like multicellular 
structure in the petiole, $R$. phaseoloides by the straight area between its petiole ridges, while $R$. melanocarpa did not present any specifically distinctive feature.

The paraveinal mesophyll was a distinct cell layer located between palisade and spongy parenchyma in the plane of the minor veins and may represent a specialized physiological compartment. It is extensively distributed among members of the Leguminosae subfamily Papilionoideae (Brubaker and Lerster 1995). Lackey (1978) did not mention the presence of a paraveinal mesophyll in species of Rhynchosia. However, we found a layer of cells between the spongy and palisade parenchyma in all species, which was also recorded by Brubaker and Lester (1995) for R. rufescens as a Mittelschicht (meaning a middle layer in the German original) in their summary of published reports of the occurrence of paraveinal mesophyll or anatomically similar tissues in Leguminosae.

Another differentiated feature in the epidermis of leaflets and petioles was the presence of elevated stomata above the level of the epidermis. The four Roraima species occur in sunny open areas of savanna, usually on small trees or shrubs, except R. phaseoloides, which grows in forest border areas (Hirt and Flores 2012). Species in these places are expected to present features of adaption to water loss and dryness, such as thick cuticles, and stomata at or below the epidermis (Appezzato-daGlória and Carmello-Guerreiro 2004). Thus, a more in-depth study of morphophysiology in these species seems appropriate to understand the function of these types of stomata in the environments occupied by Rhynchosia in Roraima. On the other hand, we observed anatomical features characteristic of adaptation to strong solar incidence, such as thick fibers, and idioblasts with potential phenolic compound content.

\section{CONCLUSIONS}

The leaflet blade and petiolar anatomy described in here were useful features for the circumscription of Rhynchosia species known from Roraima state, in northern Brazil. The anatomical features with diagnostic value were the presence and position of differenty types of glandular trichomes, discontinuity of sclerenchyma in vascular bundles in leaflets, sclerenchymal bundle sheath extensions in leaflets, the shape of the area between wings with accessory vascular bundles on the petiole and gland-like multicellular structures in the petioles. Further studies are needed to determine the nature of the gland-like multicellular structures found in the petioles of $R$. melanocarpa, $R$. phaseoloides, and $R$. schomburgkii.

\section{ACKNOWLEDGMENTS}

We thank Dr. Rodrigo Schütz Rodrigues and the Núcleo de Pesquisa e Estudo em Educação em Ciências e Matemática (Nupecem) of the Universidade Estadual de Roraima (UERR) for kindly helping us with the preparation of some plant images. Dr. Alexander Rockinger for improving the English. Staff at both Museu Integrado de Roraima and Universidade Federal de Roraima (UFRR) herbaria are thanked for supporting this study. We gratefully acknowledge anonymous reviewers and editor Dr. Claudia Keller for their valuable reviews.

\section{REFERENCES}

Appezzato-da-Glória, B.; Carmello-Guerreiro, S.M. 2004. Anatomia Vegetal. Editora Universidade Federal de Viçosa, Viçosa, 438p.

Bhattacharyya, B.; Marheshwari, J.K. 1970. Studies on extrafloral nectaries of the Leguminales. I. Papilionaceae, with a discussion on the systematics of the Leguminales. Proceedings of the Indian Academy of Sciences Plant Science Section B, 37: 11-30.

BFG (The Brazil Flora Group). 2015. Growing knowledge: An overview of seed plant diversity in Brazil. Rodriguésia, 55: 1085-1113.

Brubaker, C.L.; Lersten, N.R. 1995. Paraveinal mesophyll: review and survey of the subtribe Erythrininae (Phaseoleae, Papilionoideae, Leguminosae). Plant Systematics and Evolution, 196: 31-62.

Cândido, E.S.; Vargas, W.; Vatanparast, M.; Mansano, V.F.; Machado, S.R.; Fortuna-Perez, A.P. 2016. A new species of Eriosema (Leguminosae, Papilionoideae, Phaseoleae) from Mato Grosso do Sul, Brazil, with a secretory structure novel to the genus. Phytotaxa, 263: 122-130.

Díaz-Castelazo, C.; Rico-Gray, V.; Ortega, F.; Angeles, G. 2005. Morphological and secretory characterization of extrafloral nectaries in plants of coastal Veracruz, Mexico. Annals of Botany, 96: 1175-1189.

Fortunato, R.H. 2000. Systematic relationship in Rhynchosia (Cajaninae- Phaseoleae-Papilionoideae- Fabaceae) from neotropics regions. In: Herendeen, O.S.; Bruneau, A. (Ed.). Advances in Legume Systematics, part 9. Royal Botanical Gardens, Kew, p.339-354.

Grear, J.W. 1978. A revision of the New World species of Rhynchosia (Leguminosae-Faboideae). Memoirs of The New York Botanical Garden, 31: 1-170

Hirt, A.P.M.; Flores, A.S. 2012. O gênero Rhynchosia Lour. (Leguminosae-Papilionoideae) no estado de Roraima, Brasil. Revista Brasileira de Biociências, 10: 192-197.

Jaca, T.; Boatwright, J; Moteetee, A. 2018. Taxonomic studies of the genus Rhynchosia Lour. (Phaseoleae, Fabaceae) in South Africa: A review of section Chrysoscias. South African Journal of Botany, 117: 119-133.

Jaca, T.; Moteetee, A. 2018. Taxonomic notes on the Rhynchosia densiflora group (Phaseoleae, Fabaceae) in South Africa and its segregation from Rhynchosia section Arcyphyllum. Bothalia 48: a2305.

Johansen, D.A. 1940. Plant Microtechniques. McGraw-Hill, New York, 523p.

Kraus, J.E.; Arduin, M. 1997. Manual básico de métodos em morfologia vegetal, v.1. Editora da Universidade Federal Rural do Rio de Janeiro, Seropédica. 198p.

Lackey, J.A. 1978. Leaflet anatomy of Phaseoleae (Fabaceae, Papilionoideae) and its relation to taxonomy. Botanical Gazette, 139: 346-446. 
Lersten, N.R.; Brubaker, C.L. 1987. Extrafloral nectaries in Leguminosae: Review and orginal observations in Erythrina and Mucuna (Papilionoideae; Phaseoleae). Bulletin of the Torrey Botanical Club, 114: 437-447.

Lewis, G.P.; Mackinder, B.; Lock, M. 2005. Legumes of the World. Royal Botanic Gardens, Kew, 389p.

Marazzi, B.; Bronstein, J.L.; Koptur, S. 2013. The diversity, ecology and evolution of extrafloral nectaries: current perspectives and future challenges. Annals of Botany, 111: 1243-1250.

Melo, Y.; Córdula, E.; Machado, S.R.; Alves, M. 2010a. Morfologia de nectários em Leguminosae senso lato em áreas de caatinga no Brasil. Acta Botanica Brasilica, 24: 1034-1045.

Melo, Y.; Machado, S.R.; Alves, M. 2010b. Anatomy of extrafloral nectaries in Fabaceae from dry-seasonal forest in Brazil. Botanical Journal of the Linnean Society, 163: 87-98.

Metcalfe, C.R.; Chalk, L. 1950. Anatomy of the dicotyledons leaves, stem and wood in relation to taxonomy with notes on economy uses. Clarendon Press, Oxford, 806p.

Miotto, S.T.S. 1988. Leguminosae: Faboideae. Tribo Phaseoleac, Subtribo Cajaninae. Boletim do Instituto de Biociências, série Botânica, 43: 1-88.
Rodrigues, R.S.; Hirt, A.P.; Flores, A.S. 2012. Morfologia de plântulas das espécies de Rhynchosia (Leguminosae, Papilionoideae) de Roraima, Brasil. Acta Botanica Brasilica, 26: 585-592.

Solereder, H. 1908. Systematic anatomy of the dicotyledons. A handbook for laboratories of pure and applied Botany, v.1. Clarendon Press, Oxford, 1182p.

Tourn, G.M.; Cosa, M.T.; Roitman, G.G.; Silva, M.P. 2009. Comparative leaf anatomy in Argentine Galactia species. Boletin de la Sociedad Argentina de Botánica, 44: 25-32.

Vargas, W.; Sartori, A.L.B.; Dias, E.S. 2015. Novelties in secretory structures and anatomy of Rhynchosia (Fabaceae). Anais da Academia Brasileira de Ciências, 87: 83-93.

RECEIVED: 08/05/2018

ACCEPTED: $15 / 09 / 2018$

ASSOCIATE EDITOR: Rosy Mary Isaias 